\title{
Postfire Invasion Potential of Rush Skeletonweed (Chondrilla juncea)
}

\author{
Cecilia Lynn Kinter, ${ }^{1}$ Brian A. Mealor, ${ }^{2}$ Nancy L. Shaw, ${ }^{3}$ and Ann L. Hild ${ }^{4}$ \\ Authors are ${ }^{1}$ Botanist, Idaho Conservation Data Center, Idaho Department of Fish and Game, Boise, ID 83712; ${ }^{2}$ Director of Stewardship, The Nature \\ Conservancy in Wyoming, Lander, WY 82520; ${ }^{3}$ Research Botanist, US Department of Agriculture, Forest Service, Rocky Mountain Research Station, \\ Boise, ID 83072; and ${ }^{4}$ Associate Professor, Department of Renewable Resources, \\ University of Wyoming, Laramie, WY 82071.
}

\begin{abstract}
North American sagebrush steppe communities have been transformed by the introduction of invasive annual grasses and subsequent increase in fire size and frequency. We examined the effects of wildfires and environmental conditions on the ability of rush skeletonweed (Chondrilla juncea L.), a perennial Eurasian composite, to invade degraded sagebrush steppe communities, largely dominated by cheatgrass (Bromus tectorum L.). Recruitment of rush skeletonweed from seed and root buds was investigated on 11 burned and unburned plot pairs on Idaho's Snake River Plain following summer 2003 wildfires. Emergence from soil seedbanks was similar on burned and unburned plots in 2003 and $2004(P=0.37)$. Soils from recently burned plots $(P=0.05)$ and sterilized field soil $(P<0.01)$ supported greater emergence than did unburned field soils when rush skeletonweed seeds were mixed into the soils in the laboratory. These decreases may indicate susceptibility of this exotic invasive to soil pathogens present in field soils. Seeds in bags placed on field soil in late October 2003 reached peak germination by mid-January 2004 during a wet period; $1 \%$ remained viable by August 2004. Seedling emergence from sown plots or the native seedbank and establishment of new rosettes from root sprouts in 2003-2005 indicate that seed germination of rush skeletonweed on the Snake River Plain may be facultative, occurring in fall or spring if soil moisture is adequate, although many germinants may not survive. Stand development results primarily from root sprouting. Establishment from seed is episodic but provides for dispersal, with increasing fire frequency and size expanding the areas of disturbance available for new invasions.
\end{abstract}

\section{Resumen}

Las comunidades esteparias de "Sagebrush" de Norteamérica han sido transformadas por la introducción de zacates anuales invasores y el subsiguiente incremento del tamaño y frecuencia de los incendios. Examinamos los efectos de fuegos naturales y las condiciones ambientales en la capacidad del "Rush skeletonweed" (Chondrilla juncea L.), una compuesta perenne de Eurasia, para invadir comunidades esteparias degradadas de "Sagebrush", dominadas principalmente por "Cheatgrass" (Bromus tectorum L.). El establecimiento de "Rush skeletonweed" a partir de semilla y yemas de la raíz, posterior a los fuegos de verano del 2003, se investigó en 11 pares de parcelas quemadas y sin quemar en la planicie del río Snake en Idaho. La emergencia en el 2003 y 2004 a partir del banco de semilla del suelo fue similar $(P=0.37)$ en las parcelas quemadas y sin quemar. Suelos de parcelas recientemente quemadas $(P=0.05)$ y suelo de campo esterilizado $(P<0.01)$ produjeron una mayor emergencia que los suelos de terrenos sin quemar, esto cuando las semillas de "Rush skeletonweed" fueron mezcladas en los suelos en el laboratorio. Estas disminuciones pueden indicar susceptibilidad de esta especie exótica invasora a los patógenos del suelo presentes en el campo. Bolsas de semilla colocadas en el suelo en el campo a fines de octubre de 2003 alcanzaron su pico de germinación a mediados de enero de 2004, durante un periodo húmedo, el 1\% permaneció viable hasta agosto del 2004 . La emergencia de plántulas de parcelas sembradas o del banco nativo de semillas y el establecimiento de nuevas rosetas a partir de rebrotes en el 2003-2005 indica que la germinación de la semilla de "Rush skeletonweed" en la planicie del río Snake puede ser facultativa, ocurriendo en otoño o primavera si la humedad del suelo es adecuada, aunque las semillas germinadas en otoño puede no sobrevivir. El desarrollo de la población resulta principalmente de rebrotes de raíz. El establecimiento a partir de semilla es episódico, pero suministra semilla para la dispersión, el aumento de la frecuencia y tamaño del fuego expande las áreas de disturbio disponibles para nuevas invasiones.

Key Words: germination, sagebrush steppe, secondary invasion, seedling emergence, seed bank

\section{INTRODUCTION}

Postsettlement degradation of North American shrub-steppe communities by livestock grazing, dryland farming, and other

Research was funded by Joint Fire Sciences Project 98-IA-189 JFSP 00-1-1-03 BLM and the National Fire Plan RMRS-BOI-4.

At the time of this research, Kinter was a Postdoctoral Research Associate with the University of Wyoming and US Dept of Agriculture Forest Service, Rocky Mountain Research Station.

Correspondence: Ann L. Hild, Dept of Renewable Resources, University of Wyoming, Box 3354, Laramie, WY 82071. Email: annhild@uwyo.edu

Manuscript received 31 August 2006; manuscript accepted 29 April 2007 land use practices have created a niche for invasion by exotic annual grasses, particularly cheatgrass (Bromus tectorum L.) and medusahead (Taeniatherum caput-medusae [L.] Nevski; Whisenant 1990, USDA NRCS 2005). Early summer senescence and production of fine fuels by annual grasses have lengthened fire seasons and increased fire frequency, further escalating loss of shrub/bunchgrass communities and altering ecosystem functioning (D'Antonio and Vitousek 1992; Prater and DeLucia 2006; Prater et al. 2006). Whisenant (1990) estimated that more than 40 million ha of the Intermountain West had been invaded by cheatgrass. In the Snake River Birds 
of Prey National Conservation Area of southern Idaho, the firereturn interval declined from 81 years in 1950 to 27 years between 1980 and 1995 (USDI 1996).

Secondary invasions are more likely and rapid because introduced species can alter community function (Simberloff and Von Holle 1999; Dayan and Simberloff 2005). In sagebrush-steppe ecosystems of the Intermountain West, the current cheatgrass-wildfire cycle may be an intermediate step that facilitates invasion of exotic perennials that are even more difficult to control (Roche and Roche 1991). Perennials that have deep rooting systems and the ability to spread vegetatively also exhibit greater tolerance of fire. By understanding the potential expansion of these species in degraded shrub-steppe communities, we may identify links between their reproductive biology and the mechanisms facilitating their spread.

Rush skeletonweed or gum succory (Asteraceae: Chondrilla juncea L.) is a wiry Eurasian perennial invader appearing relatively recently on the western Snake River Plain (SRP) in southwestern Idaho and adjacent areas in eastern Oregon. In southern Idaho, it was first recorded in foothill and montane habitats in 1963 (Middlemist 1966). By 1976, the original 8-ha infestation had grown to an estimated 930000 ha (Ross 1976). Despite its rapid spread at midelevations, rush skeletonweed occupied a relatively small portion of drier shrub-steppe communities to the south by 1979 (Baysinger and Lee 1980). It has gradually become more widespread in recent years, sometimes forming extremely dense stands. Infestations are most commonly observed on abandoned farmland, annual grasslands, roadsides, and other disturbed areas.

Rush skeletonweed has been designated a Noxious Weed in 8 states of the United States and in British Columbia, Canada, yet few studies of its biology and ecology in North America have been published. In Australia, it has been a notorious invader of grain fields since the 1910s (Judd and Carn 1935). Under Australian field conditions, rush skeletonweed may yield 15 000-27 000 achenes (seeds) $\cdot$ plant $^{-1}$ (McVean 1966; Dodd and Panetta 1987; Panetta and Dodd 1987), and it appears similarly prolific on the SRP. Apomictically produced seeds ripen and are dispersed from mid-July until first frosts (Liao et al. 2000) and are dispersed by wind, animals, vehicles, machinery, and water (Panetta and Dodd 1987; Sheley et al. 1999). Rush skeletonweed also spreads vegetatively from adventitious root buds, and these sprout particularly vigorously when plants are damaged (Cuthbertson 1972; Panetta and Dodd 1987; A. Hild and N. Shaw, personal observation 2007).

Chemical and mechanical control efforts are often conducted to reduce seed production and prevent establishment of new infestations (see, for example, Boerboom 1993; Pratt and Pierce 2002; Ministry of Agriculture and Lands 2004). In Australia, however, McVean (1966) suggested that consistently hot summer weather (daily maxima exceeding $33^{\circ} \mathrm{C}$ ), with low relative humidity and soil moisture, reduces rush skeletonweed seed production and viability. On the SRP, daily temperatures routinely exceed $33^{\circ} \mathrm{C}$ in July and August and monthly precipitation typically averages less than $20 \mathrm{~mm}$ from June to October (NOAA 2002).

Factors affecting the ability of rush skeletonweed to expand across the SRP and into the northern Great Basin have not been evaluated. Fire tolerance and rapid spread following fire could be inferred from its vegetative reproduction potential, deep rooting habit, long flowering period, and the potential for longdistance dispersal of its tiny seed. Rush skeletonweed has been anecdotally reported to increase after fire (Asher et al. 1998), yet an extensive literature review in the Fire Effects Information System (Zouhar 2003) revealed little about its response to fire. To determine whether recently burned areas are more favorable to rush skeletonweed seed germination and seedling establishment than unburned areas supporting competitive vegetation, we contrasted 11 recently burned and paired unburned shrubsteppe plots on the SRP. To test our hypothesis that fire enhances seedling recruitment of rush skeletonweed in burned vs. unburned plots, we examined 1) rush skeletonweed seed banks for presence, viability, and longevity of seed, 2) seedling emergence from native soils in the field and under optimum laboratory conditions, and 3) the relative proportion of new rosettes derived from seed and root buds within existing rush skeletonweed stands.

\section{METHODS}

\section{Study Sites}

The study area spans a distance of about $60 \mathrm{~km}$ across the primary region of rush skeletonweed invasion into the northern edge of the SRP near Boise, Idaho. Vegetation consists of former shrub-steppe communities once dominated by subspecies of big sagebrush (Artemisia tridentata Nutt.), particularly Wyoming big sagebrush (A. $t$. Nutt. ssp. wyomingensis Beetle \& Young) and basin big sagebrush (A. t. Nutt. subsp. tridentata); antelope bitterbrush (Purshia tridentata [Pursh] DC.); and bunchgrasses, including bluebunch wheatgrass (Pseudoroegneria spicata [Pursh] A. Löve), Thurber's needlegrass (Achnatherum thurberianum [Piper] Barkworth), and Sandberg bluegrass (Poa secunda J. Presl). Invasive annual grasses, primarily cheatgrass and medusahead, and seeded perennial grasses, including desert wheatgrass (Agropyron desertorum [Fisch ex. Link] J.A. Schultes) and intermediate wheatgrass (Thinopyrum intermedium [Host] Barkworth \& D.R. Dewey), now dominate much of the area.

Eleven rush skeletonweed stands, each situated on uniform terrain and straddling fire lines of 4 current year's burns were identified in late summer 2003 (Table 1). Stands all lie below $1500-\mathrm{m}$ elevation and a variety of slopes and aspects are represented (Table 1). Soils are well drained and moderately deep to very deep. Average yearly precipitation at Boise is about $309 \mathrm{~mm}$, most of which falls from November through May (NOAA 2004). Most sites are grazed by cattle (Bos taurus) or mule deer (Odocoileus hemionus), with additional use by small mammals. None of the sites appear to have been plowed in the past, but soil disturbances by rabbits (Lepus californicus and Sylvilagus nuttallii), rodents (Spermophilus townsendii), and American badgers (Taxidea taxus) were also present.

At each of the 11 locations, 1 permanent $10 \times 20 \mathrm{~m}$ plot was established at least $5 \mathrm{~m}$ and within $30 \mathrm{~m}$ of each side of the fire line for repeated nondestructive sampling, including density and canopy cover of rush skeletonweed and other vegetation. Soil seed bank and seed ecology studies described below were conducted around the perimeter of these plots (Fig. 1). 
Table 1. Postfire ${ }^{1}$ study sites along the northern border of Idaho's Snake River Plain ${ }^{2}$ and surrounding foothills used for assessment of rush skeletonweed reproductive traits.

\begin{tabular}{lcccll}
\hline \multicolumn{1}{c}{ Site } & $\begin{array}{c}\text { Elevation } \\
(\mathrm{m})\end{array}$ & $\begin{array}{c}\text { Slope } \\
(\%)\end{array}$ & $\begin{array}{c}\text { Aspect }{ }^{3} \\
\left({ }^{\circ}\right)\end{array}$ & \multicolumn{1}{c}{$\begin{array}{c}\text { Soil texture } \\
(\text { class })\end{array}$} & \multicolumn{1}{c}{$\begin{array}{c}\text { Associated vegetation } \\
\text { (species) }\end{array}$} \\
\hline Railroad & 797 & 0 & N/A & Fine sandy loam & Poa secunda/Bromus tectorum \\
Fence & 800 & 8 & 204 & Fine loam/silt loam & Poa secunda/Bromus tectorum/Vulpia octoflora \\
Top & 845 & 12 & 174 & Fine loam/silt loam & Poa secunda/Bromus tectorum/Vulpia octoflora \\
Cactus & 797 & 9 & 243 & Fine loam/silt loam & Bromus tectorum/Amsinckia retrorsa \\
Pond & 798 & 10 & 192 & Fine loam & Bromus tectorum/Taeniatherum caput-medusae/Erodium cicutarium \\
Ridge & 996 & 44 & 188 & Very gravelly loam & Poa secunda/Bromus tectorum/Erodium cicutarium \\
Ravine & 970 & 21 & 234 & Very gravelly loam & Poa secunda/Bromus tectorum/Erodium cicutarium \\
Walk-in & 956 & 30 & 140 & Sandy and gravelly loam & Erodium cicutarium/Poa bulbosa/Taeniatherum caput-medusae \\
Knob & 1119 & 33 & 335 & Sandy and gravelly loam & Purshia tridentata/Agropyron spp./Poa bulbosa \\
Flattop & 1177 & 0 & N/A & Very gravelly loam & Artemisia tridentata/Poa secunda \\
East & 1253 & 13 & 83 & Loam/gravelly loam & Agropyron spp. /Poa bulbosa \\
\hline
\end{tabular}

${ }^{1}$ Burn dates were 25 June to 16 August 2003.

${ }^{2}$ Locations were lat $43^{\circ} 30^{\prime} \mathrm{N}$ to $43^{\circ} 50^{\prime} \mathrm{N}$ and long $116^{\circ} 03^{\prime} \mathrm{W}$ to $116^{\circ} 41^{\prime} \mathrm{W}$.

${ }^{3} \mathrm{~N} / \mathrm{A}$ indicates not applicable.

\section{Seed Sources}

All seeds used in the manipulative experiments (seed bank in field soils, influence of native soils on seedling emergence and dormancy, and germination and emergence of buried seeds)
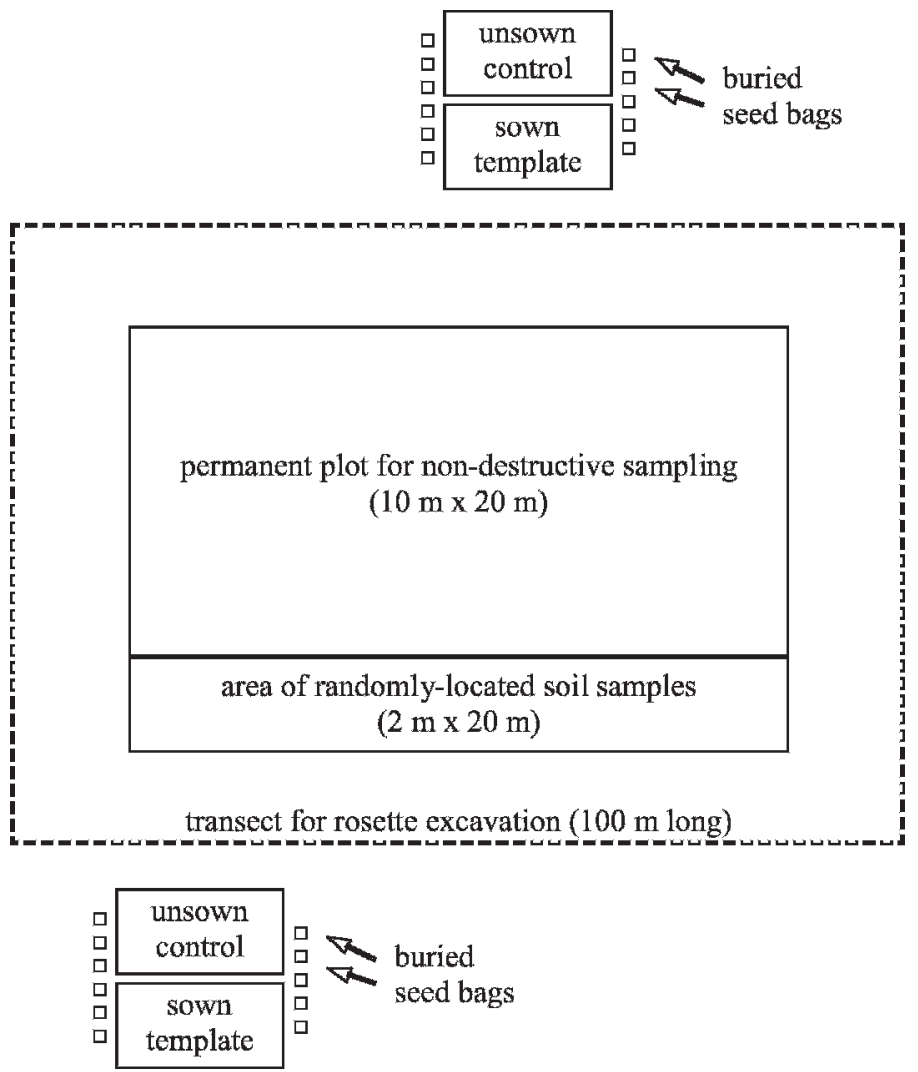

Figure 1. Layout of field plot showing positions of each sampling (not drawn to scale). Total size of the area for 1 replication of buried seed bags, a sown template, and unsown control is about $0.9 \times 0.9 \mathrm{~m}$. This design was repeated on both sides of the fireline at 11 study sites on the Snake River Plain, Idaho, with the exceptions that seed bags and templates were not planted at the East site and 1 additional template was sown at the Flattop, Ridge, Top, and Pond locations. were hand-collected from 3 dense stands (Eisenman, Orchard, and Simco) of rush skeletonweed located at least $10-\mathrm{km}$ apart and more than $2 \mathrm{~km}$ from the nearest study site. We assumed that the hand-collected seeds were genetically similar to those present at the study sites because of the obligate apomictic nature of rush skeletonweed (Cuthbertson 1974), and longstanding reports of a single "morphotype" being present in the region (Lee 1986; McCaffrey et al. 1996). Seed collection sites were located between lat $43^{\circ} 15^{\prime} \mathrm{N}$ and lat $43^{\circ} 31^{\prime} \mathrm{N}$ and long $116^{\circ} 04^{\prime} \mathrm{W}$ and long $116^{\circ} 57^{\prime} \mathrm{W}$. The environment at these sites was comparable to the study sites in terms of topography, vegetation, and climate. Elevations ranged from 953 to $956 \mathrm{~m}$, and soils varied from a silt loam/silty clay loam to a sandy loam/sandy clay loam.

Seeds were collected on 7 dates over the seed ripening and dispersal period, approximately every week from mid-August to early October 2003. Seeds were air-dried, hand cleaned to remove pappi, and stored in sealed amber glass jars in the laboratory. The 50-seed sets used in the manipulative experiments comprised a hand-counted, unsterilized mixture of filled, mature seeds of approximately equal numbers from the 3 sites and 7 collection dates. For seeds mixed into native soils collected 27 October 2003, we used seeds from 2 early October 2003 collection dates. In a preliminary test, total germination percentage of seed from 4 of these collection dates was $50 \%-$ $59 \%$, and germination was complete by day 10 (data not shown).

\section{Seed Bank in Field Soils}

Soil seed banks were assessed on 6 and 20 October 2003 and 17 October 2004, near the end of both the fruiting period and the summer dry season (Fig. 2). Few seeds remained in the aerial seed bank on these dates. Randomly located soil samples and their surface litter were collected from each burned and unburned plot. Each sample was a composite of 4 cores, each $5 \mathrm{~cm}$ in diameter by $4-\mathrm{cm}$ deep. Five replicate samples were collected per plot, providing a total surface area of $392.7 \mathrm{~cm}^{2}$ and a volume of $1570 \mathrm{~cm}^{3}$. This exceeded the $200 \mathrm{~cm}^{3}$ (Forcella 1984) and $500-600 \mathrm{~cm}^{3}$ (Hayashi 


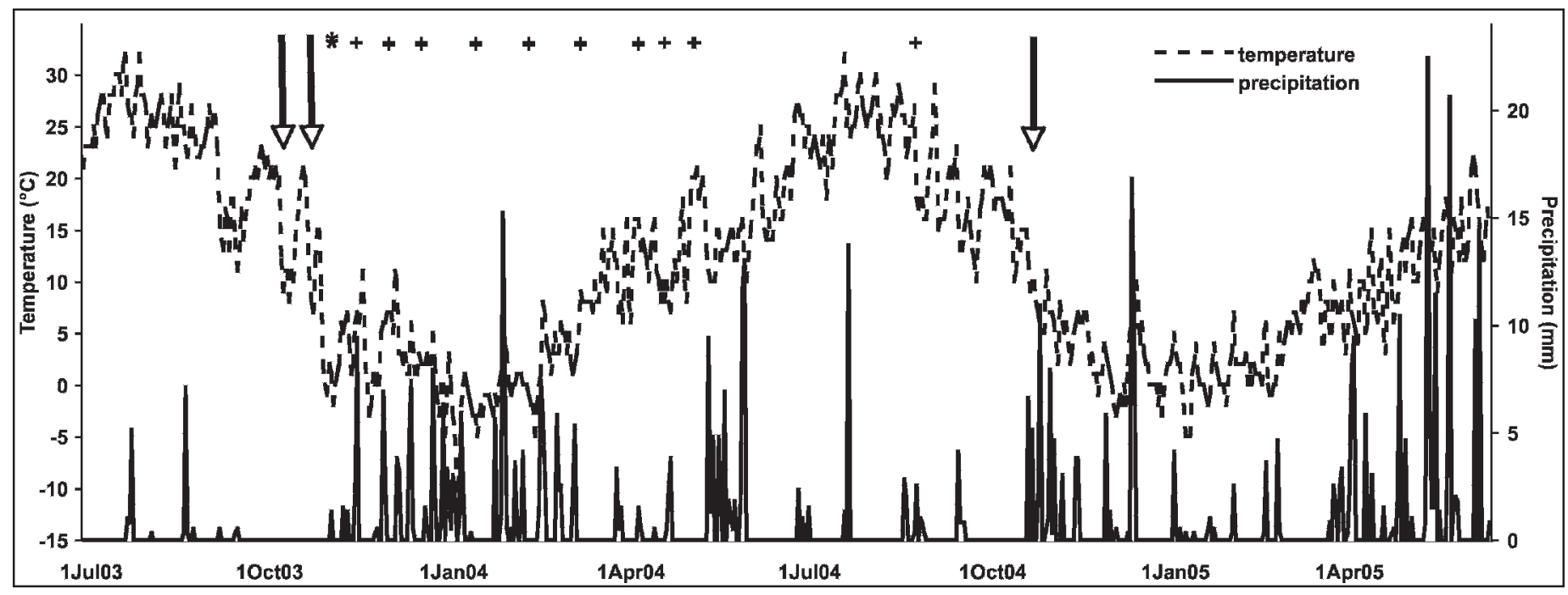

Figure 2. Daily mean temperature and daily total precipitation for Boise, Idaho, during the time period of our study. Solid arrows indicate soil seed bank collection dates. The date of burying seed bags and sowing seeds in the field is marked with an asterisk; plus signs indicate dates of retrieving seed bags and counting emergent seedlings.

and Numata 1971) reported adequate for grassland seedbank analyses. The 4-cm sample depth was chosen because Cuthbertson (1970) reported essentially no emergence when rush skeletonweed seeds were sown at depths $>4 \mathrm{~cm}$.

Samples were placed in soil tins and packed in a cooler with ice for transport to the laboratory. Each sample was then spread 1-cm deep over a 2-cm-deep layer of clean, sterilized sand in a plastic tray for incubation in growth chambers. To test this system in 2003, we also prepared 4 additional trays of more than 50 hand-collected seeds mixed in potting soil and spread over sand. In 2004, we prepared 10 additional trays of clean, sterilized sand, sown with 50 seeds each, and to assess the viability of these seeds, we placed 10 additional sets of 50 seeds on blotter paper in $11 \times 11 \times 4 \mathrm{~cm}$ clear plastic germination boxes. All trays and boxes were watered with tap water and placed in a growth chamber at $23^{\circ} \mathrm{C}(12 \mathrm{~h}$ light $/ 12 \mathrm{~h}$ dark). All containers were watered and rerandomized every other day to minimize shelf placement effects. At the end of weeks 4 and 6 , rush skeletonweed emergents (cotyledon emerged $>1 \mathrm{~mm}$ ) were counted and removed. No emergence occurred after week 6, and emergence totals (wk $4+$ wk 6) were used for analysis. Germinants were counted and removed from the germination boxes after day 7 and day 12 . No additional germination occurred after day 12 , and germinant totals $(\mathrm{d} 7+\mathrm{d} 12)$ were used as denominators for percentage emergence calculations.

Seed bank emergence data for rush skeletonweed in burned and unburned field soils were nonnormal and noncorrectable. Means were separated with the nonparametric Multi-Response Block Permutation (MRBP) procedure (Mielke and Berry 2001) using a randomized complete-block design with site as a blocking factor, burns as the treatment, and collection dates as repeated measures. Means were separated using multiple comparisons based on Peritz Closure (Petrondas and Gabriel 1983).

\section{Influence of Native Soils on Seedling Emergence}

To examine the effect of native soils on rush skeletonweed seeds, a single randomly located soil sample consisting of 4 cores, each $5 \mathrm{~cm}$ in diameter and 4-cm deep, was collected from each burned and unburned plot (22 samples total) on 27 October 2003 as described for the soil seed bank analysis. Fifty seeds were mixed into each of the air-dried soil samples and into each of 10 controls of clean, sterilized sand. Five additional replicates of 50 seeds were stored in envelopes in the laboratory. After an 8-week dry-incubation period, approximately the time period seeds might be expected to lay in dry soil in early fall, the samples in soil and sand were spread over trays of sand, and the 5 extra seed replicates were placed on blotters in germination boxes. Incubation and counts of emergence and germination were conducted as described above for the soil seed-bank analysis. To account for the small influence of rush skeletonweed seeds present in the seed bank before the 50 test seeds were added, we adjusted the emergent count data by subtracting the values from the 2003 soil seed-bank study for the corresponding plot.

In 2004, we refined our method of sowing seeds into native soil and conducted an additional test. On 17 October 2004, 2 sets of soil samples were collected from each plot in addition to the 5 sets collected for soil seed-bank analysis. Two samples from each plot were randomly selected for this experiment: 1 of these was sterilized to kill soil microorganisms (autoclaving at $121^{\circ} \mathrm{C}$ steam, 6.8 - $\mathrm{kg}$ pressure, 2 hours on each of 2 consecutive days). Fifty seeds were mixed into each sterilized and unsterilized sample and into an additional 10 controls of sterilized sand (the same 10 control trays used for the soil seed-bank analysis). To assess seed viability, 10 additional sets were placed on damp blotter paper in germination boxes. All trays and boxes were set in a growth chamber concurrently with the soil seed-bank samples. Germinants and emergents were counted as described previously. To account for background emergence from unsterilized soils, counts were reduced for 
these samples by the corresponding emergence from the soil seed-bank samples from the corresponding plot.

The influence of native burned and unburned soils on seedling emergence from planted seeds was analyzed using the SAS GLIMMIX procedure, fitting a logistic model to the data. Data from the 2003 and 2004 experiments were analyzed separately.

\section{Dormancy, Germination, and Emergence of Buried Seeds}

To assess seed dormancy, germination, longevity, and emergence under field conditions, we established sets of buried seed bags, sown seeds, and laboratory controls on 30-31 October 2003 to be monitored over the following 10 months. To minimize the confounding influence of emergents from roots, we located each set to avoid existing rush skeletonweed plants. The East site was too densely populated by rush skeletonweed to provide an opening, so it was not used. Two replicates of 11 mosquito net seed bags $(5 \times 5 \mathrm{~cm})$, each containing 50 hand-collected seeds, were buried on each burned and unburned plot (11 bags $\times 2$ replicates $\times 2$ burn states $\times 10$ plots; Fig. 1$)$. Each bag was staked to the soil surface with a $12-\mathrm{cm}$-long bamboo skewer, and covered with approximately $1 \mathrm{~cm}$ of loose soil collected nearby. This depth was chosen because surface sowing and sowing at depths greater than $1 \mathrm{~cm}$ were shown to reduce seedling emergence in Australia (Cuthbertson 1970; Panetta 1984). Where substantial litter was present at a site, litter was also placed over the soil to mimic surrounding conditions. Fifty-five additional seed bags were held as controls at room temperature in a dark drawer in the laboratory.

Adjacent to the bags in the field, we sowed 50 seeds in 5 rows of 10 seeds. A $7-\mathrm{cm}$ seed spacing was consistently maintained using a Plexiglas template with holes arranged in a rectangular grid. Each seed was sown $1-\mathrm{cm}$ deep in a narrow hole made with a dissecting needle. At 4 of the sites (Flattop, Ridge, Top, Pond), we sowed 50 additional seeds adjacent to the first replicate because we suspected that harsh site conditions would result in low numbers of emergents. Adjacent to each template, an area of the same size was designated as a control to check for naturally occurring seedlings. To protect the seed bags and sown seeds from disturbance by rabbits, livestock, or off-road vehicles, we covered each set with a woven wire pyramid, $1.5 \times$ $1.5 \mathrm{~m}$ along the base and approximately 2-m tall with the bottom $0.6 \mathrm{~m}$ wrapped in chicken wire.

Beginning 14 November 2003, we removed a single buried seed bag at random from each replicate set, placed it in a cooler with ice, and returned the 40 collected bags to the laboratory for immediate counting of germinated seeds. Nongerminated seeds from each seed bag as well as 5 sets of 50 laboratorystored control seeds were placed in germination dishes in growth chambers and incubated as described previously. After 7 days, all emergents were counted and removed. Nongerminated seeds were left in the boxes and reassessed after an additional 7 days. To test for dormancy, any seeds that failed to germinate after 14 days were touched gently with the edge of a dissecting needle to determine whether they were empty, mushy, or plump. Empty or mushy seeds were considered nonviable. Plump seeds were tested with tetrazolium following Peters (2000) to determine viability. Because less than $2 \%$ of all seeds were still plump, and none were viable on 8 March 2004, we discontinued tetrazolium testing after that date.

This procedure of retrieving seed bags and analyzing the contents was repeated every 2 weeks in fall and spring and every 4 weeks in winter. Retrieval dates were 14 November and 1 and 15 December in 2003 and 12 January, 9 February, 8 March, 5 and 19 April, and 3 May in 2004. On 23 August 2004, we retrieved a 10th set in which most of the germinants had decayed and could not be counted, but intact seeds were tested for viability as described previously. On the same dates as seed-bag retrieval, the original planting template was reregistered over each seeded grid using permanently placed pins and used to locate and follow each emergent seedling. In addition, the control areas were examined for the presence of naturally occurring seedlings by digging up potential seedlings and confirming the presence of cotyledons and fine roots.

Field, laboratory, and total germination data for seed from the buried seed bags were analyzed using PROC MIXED (SAS 2003) with burn status as treatments, sites and site $\times$ treatment as random effects, and weeks after burial as repeated measures. Means were separated using Bonferroni comparisons. Data from the planting grids were not analyzed statistically because few seedlings emerged.

Total germination obtained when seeds were incubated in germination boxes on each collection date for each of these 3 studies (soil seed bank, influence of native soils on seedling emergence, and dormancy, germination, and emergence of buried seeds) was used as an estimate of germinable seeds. Seedling emergence from seeds planted in potting soil or sterilized sand on each collection date for each experiment was calculated for comparison.

\section{Source of New Rosettes From Seeds or Root Buds}

On the SRP, rush skeletonweed rosettes typically appear in fall and spring. Most fall emergents appear to senesce or die in winter, and all rosettes wither away as the plants bolt in May and June. Some rosettes emerge at the base of an existing stem; others occur away from an existing stem as "new" rosettes and may originate from either a root bud or a seed. To determine the source of new individuals, we excavated up to 20 rosettes plot $^{-1}$ every 2 weeks in fall 2003 and spring 2004 and every 4 weeks from fall 2004 through spring 2005. New rosettes were examined along a 2 -m-wide by $100-\mathrm{m}$-long belt transect positioned around the periphery of the permanent plot. We randomly chose rosettes that were $\leq 5 \mathrm{~cm}$ in diameter, not adjacent to an existing stem, and at least $2 \mathrm{~m}$ from another excavated rosette because single roots tend to produce several shoots (Rosenthal et al. 1968). No more than 20 rosettes were chosen per plot, and we typically found less than 20 . Rosettes were recorded as seedlings, if they possessed fresh or dried cotyledon leaves and fine seedling roots, or as root buds, if they lacked cotyledon leaves and had a single thick root sprouting from a larger lateral root. We had previously examined other rosettes grown from seeds and rosettes clearly attached to lateral roots in the field. We excavated more rosettes in fall 2003 and spring 2004 than in fall 2004 and spring 2005 because there were more rosettes present in the first 2 seasons. Data on the source of new rosettes from roots or seed were not analyzed statistically because few seedlings were found. 

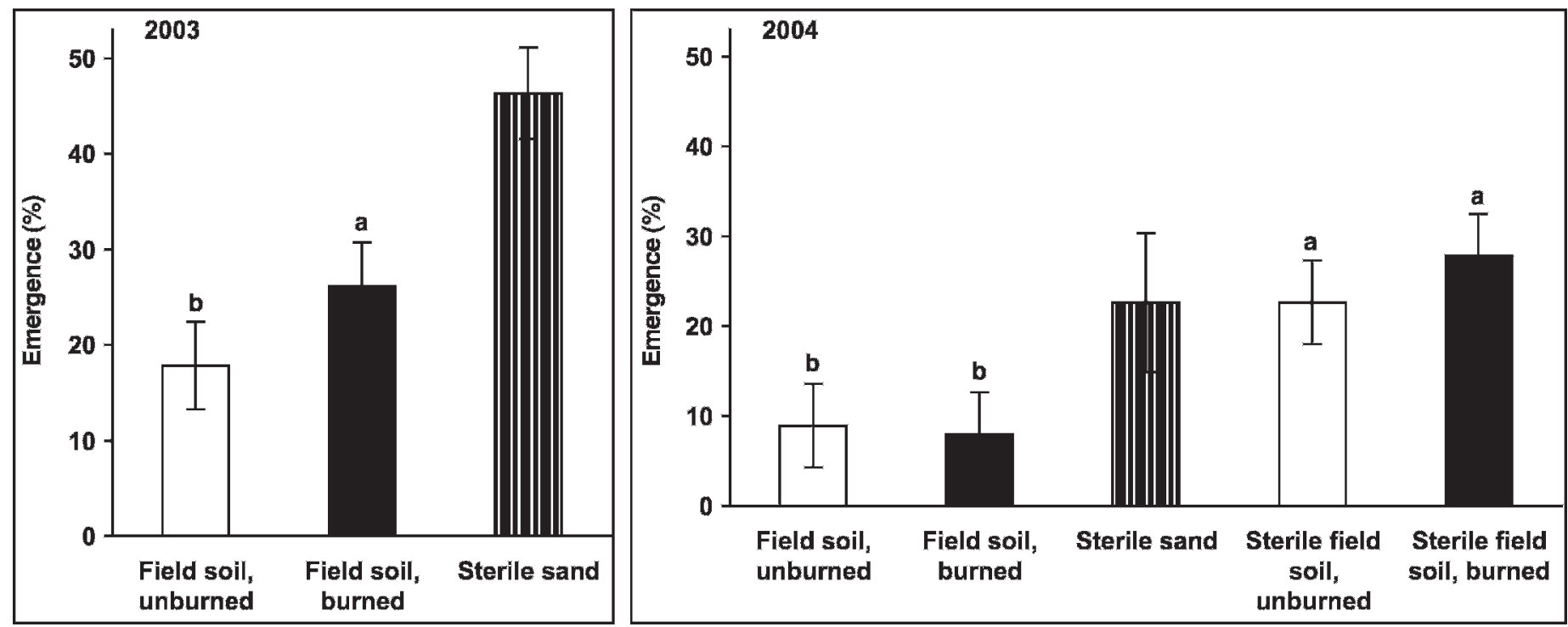

Figure 3. Emergence of rush skeletonweed (percentage of germinable seed) when incubated in soils collected on unburned and burned plots or sterile sand in 2003. In 2004, seeds were also incubated in sterilized soil from unburned and burned plots. Within years, treatments with the same letters do not differ $(P>0.05)$. Error bars indicate \pm 1 SE $(n=11$ for field soils and $n=10$ for sterile sand).

\section{RESULTS}

\section{Seed Bank in Field Soils}

Laboratory emergence of rush skeletonweed from field soils was similar on the 2 (6 and 20 October 2003) collection dates $\left(55.6 \cdot \mathrm{m}^{-2}\right)$ but lower than from soils collected on 17 October $2004\left(140.1 \cdot \mathrm{m}^{-2} ; P<0.01\right.$; data not shown). Emergence was not statistically different for seeds from unburned $\left(118.8 \cdot \mathrm{m}^{-2}\right)$ and burned plots $\left(48.6 \cdot \mathrm{m}^{-2} ; P=0.37\right)$, regardless of year. However, emergence varied widely among sites; the range in 2004, for example, was from 0 to 1095 emergents $\cdot \mathrm{m}^{-2}$. Seed banks in soils collected in 2003 and 2004 ranged from 93 to 164 emergents $\cdot \mathrm{m}^{-2}$ for unburned plots and from 14 to 116 emergents $\cdot \mathrm{m}^{-2}$ for burned plots. Emergence in test trays was about $50 \%$ of germinable seeds in 2003 , and $23 \%$ in 2004 , indicating that the actual soil seed bank could be 2 and 4 times higher than the levels found.

\section{Influence of Native Soils on Seedling Emergence}

In 2003, emergence of germinable seed was greater from burned than from unburned field soils $(P=0.05$; Fig. 3$)$. In 2004 , emergence of germinable seed was greater from sterilized than from unsterilized field soils indicating a 3-fold decrease because soil biota $(P<0.01$; Fig. 3$)$. The burn treatment did not interact with the sterilization treatment $(P=0.26)$ nor was the burn treatment main effect significant $(P=0.63)$ at this time.

\section{Dormancy, Germination, and Emergence of Buried Seeds}

Seeds in bags buried on 30-31 October 2003 began germinating on unburned sites by 14 November 2004 and on burned sites by 1 December 2004 (Table 2). Germination in the field differed among retrieval dates $(P<0.01)$ for both burned and unburned plots. Field germination increased until the 12 January 2004 retrieval date and then remained unchanged at about $31 \%$ until the end of the study. There was no significant interaction of burn status by retrieval date $(P=0.07)$, and germination did not differ between unburned and burned plots $(P=0.15)$.

When ungerminated seeds from field-retrieved bags were incubated in the laboratory, germination was low and comparable for burned and unburned sites on 14 November 2004, greater for burned than unburned sites on 1 and 15 December 2003, and similar thereafter $(P<0.01)$, suggesting an initial lag in field germination on burned sites. No differences due to burn status were noted after this date; laboratory germination dropped to less than $2 \%$ by 8 March 2004 and about $1 \%$ of retrieved seeds remained germinable on

Table 2. Field and laboratory germination (percent \pm SE) of rush skeletonweed seeds in bags buried 30-31 October 2004 on 10 burned and unburned plot pairs. On 9 dates, bags were retrieved and examined for field germination and viable ungerminated seed in the laboratory following field retrieval. Laboratory germination values (viable ungerminated seed) with different lowercase letters differ $(P<0.05)$ between burn states within dates. Field germination values did not differ between burn states $(P>0.05)$.

\begin{tabular}{lccccc}
\hline \multirow{2}{*}{$\begin{array}{l}\text { Retrieval } \\
\text { date }\end{array}$} & \multicolumn{2}{c}{ Field germination $(\% \pm \mathrm{SE})$} & & \multicolumn{2}{c}{ Laboratory germination $(\% \pm \mathrm{SE})$} \\
\cline { 2 - 3 } \cline { 5 - 6 } \cline { 5 - 6 } 14 Nov 2003 & \multicolumn{1}{c}{ Burned } & Unburned & & Burned & Unburned \\
1 Dec 2003 & $15.9 \pm 3.0$ & $2.9 \pm 1.9$ & & $47.4 \pm 1.4$ & $40.8 \pm 2.7$ \\
15 Dec 2003 & $22.4 \pm 1.8$ & $28.9 \pm 2.3$ & & $20.2 \pm 3.0 \mathrm{a}$ & $11.3 \pm 2.1 \mathrm{~b}$ \\
12 Jan 2004 & $28.1 \pm 1.7$ & $27.3 \pm 1.7$ & & $9.0 \pm 1.5 \mathrm{a}$ & $3.1 \pm 0.9 \mathrm{~b}$ \\
9 Feb 2004 & $28.9 \pm 3.0$ & $34.1 \pm 2.5$ & & $4.3 \pm 1.0$ & $3.5 \pm 0.6$ \\
8 Mar 2004 & $28.9 \pm 1.8$ & $30.5 \pm 1.6$ & & $1.0 \pm 0.3$ & $1.5 \pm 1.0$ \\
5 Apr 2004 & $32.2 \pm 2.4$ & $27.4 \pm 2.2$ & & $0.5 \pm 0.3$ & $0.8 \pm 0.4$ \\
19 Apr 2004 & $29.8 \pm 2.7$ & $34.3 \pm 3.7$ & & $0.7 \pm 0.3$ & $0.4 \pm 0.2$ \\
3 May 2004 & $33.0 \pm 3.8$ & $32.3 \pm 2.8$ & & $0.5 \pm 0.2$ & $0.4 \pm 0.2$ \\
23 Aug 2004 & $\mathrm{N} / \mathrm{A}^{1}$ & $\mathrm{~N} / \mathrm{A}^{1}$ & & $1.2 \pm 0.3$ & $1.1 \pm 0.5$ \\
\hline
\end{tabular}

${ }^{1}$ Data not available because of seed decomposition. 
Table 3. Source of excavated rush skeletonweed rosettes (root buds or seed), on 11 unburned and burned plot pairs on the Snake River Plain, Idaho. On each sampling date a maximum of 20 rosettes $^{1}$ were sampled from a $2 \times 100 \mathrm{~m}$ belt transect around the periphery of the permanent plot. Data are seasonal totals.

\begin{tabular}{lcrrrrr}
\hline & & \multicolumn{2}{c}{ Root buds } & & \multicolumn{2}{c}{ Seed } \\
\cline { 3 - 4 } \cline { 6 - 7 } Season & Sampling dates & Unburned & Burned & & Unburned & Burned \\
\hline Fall 2003 & 6 & 78 & 463 & & 0 & 2 \\
Spring 2004 & 6 & 209 & 364 & & 0 & 2 \\
Fall 2004 & 4 & 45 & 64 & & 0 \\
Spring 2005 & 4 & 137 & 155 & & 35 & 73 \\
Total & & 469 & 1046 & & 35 & 77 \\
\hline
\end{tabular}

${ }^{1}$ Rosettes sampled were $<5 \mathrm{~cm}$ in diameter, not adjacent to an existing stem, and at least $2 \mathrm{~m}$ from another existing rosette.

23 August 2004. It is not clear whether those remaining germinable seeds had been dormant or simply lacked enough available moisture to germinate in the field. Total field and laboratory germination varied only with weeks after planting and reached a maximum 2 weeks after sowing $(P<0.01)$, which did not change over time thereafter.

Of the 2800 seeds sown directly into soil in the field on 3031 October 2003, no seedlings were documented during fall and winter (data not shown). Two seedlings were found on 19 April 2004, and 2 were found on 4 May 2004, resulting in a total emergence of $0.1 \%$. None of the 4 emergents survived to the bolting stage. No seedlings were found in the adjacent unsown control areas.

\section{Source of New Rosettes From Seeds or Root Buds}

Most of the 1627 excavated rosettes originated from root buds (Table 3). During fall 2003, spring 2004, and fall 2005 emergence periods, few of the rosettes excavated $(0.3 \%)$ were seedlings. However, in spring 2005, nearly 2 years after the burns, $27 \%$ of the 400 rosettes excavated were seedlings (originated from seed rather than adventitious roots), and more seedlings were found on burned than on unburned plots.

\section{DISCUSSION}

\section{Effects of Fire on Seed Banks}

Soil seed banks were expected to be near their maximum when soil samples were taken in October 2003 and 2004. Seed bank development on the burned sites would have occurred via dispersal from nearby unburned areas and from seeds produced by recovering burned plants following the fires, which occurred from 25 June to 16 August 2003. By October 2003, there were about one-half as many flower seed stalks ${ }^{-1}$ on burned compared with nonburned sites (data not shown). Rush skeletonweed soil seed banks on burned and unburned plot pairs (as determined by seedling emergence from laboratory incubated soils) did not differ in fall 2003 or 2004, although considerable variability did occur among locations and between plots. Seedling emergence was low when compared with similar data for other exotic members of the Asteraceae invading Intermountain shrub steppe. For example, Stringer (2003) documented seed banks of 3900-6 715 emergents $\cdot \mathrm{m}^{-2}$ in the top $10 \mathrm{~cm}$ of soil for spotted knapweed (Centaurea stoebe L. subsp. micranthos [Gugler] Hayek; previously Centaurea maculosa Lam.), a perennial, whereas McEvoy et al. (1991) documented 4 300-14500 emergents $\cdot \mathrm{m}^{-2}$ in the top $10.5 \mathrm{~cm}$ of soil for tansy ragwort (Senecio jacobaea L.), usually a biennial. These species develop persistent seed banks (McEvoy et al. 1991; Davis et al. 1993), in contrast to our findings ( $1 \%$ remaining after $1 \mathrm{y})$ and to Australian research that estimated $<6$ months survival of rush skeletonweed seeds in the field (Cullen and Groves 1977). In contrast to rush skeletonweed, however, neither of these species spreads vegetatively.

Recently burned field soil (2003, but not 2004 field samples), sterilized field soil, and sterilized sand all supported greater seedling emergence than unburned field soil when equal numbers of hand-collected seeds were added to the samples in the laboratory (Fig. 3). Loss of seed in native soil versus sterilized or burned soils seems to suggest the impact of soil pathogens. Such pathogens are known to be common in sagebrush steppe ecosystems, with small seeds generally being more susceptible (Crist and Friese 1993). We did not identify soil pathogens or other factors acting to reduce rush skeletonweed seed within the soil. Differences in emergence of handcollected seed from burned and unburned field soils were not noted in fall 2004, indicating that fire effects on soil pathogens or other unidentified factors may have been ameliorated. Seed loss of an exotic species to native pathogens might not be expected if its success as an invader results from a lack of predators as described by the invasion meltdown hypothesis (Simberloff and Von Holle 1999). Blaney and Kotanen (2001, 2002), however, found no consistent difference between natives and exotics in the susceptibility of their seeds to soil pathogens and concluded that many seed pathogens are generalists. The possible impact of native sagebrush steppe soil pathogens on rush skeletonweed seed deserves further study.

\section{Field Germination}

Field germination in seed bags did not differ between burned and nonburned sites on any date. Greater laboratory germination of seeds remaining in seed bags from the burned compared with the nonburned sites on the 1 and 15 December 2003 retrieval dates may indicate an initial lag in field germination following fire.

Because viable rush skeletonweed seeds from our seed collection sites germinated in $<10$ days at temperatures from $6-30^{\circ} \mathrm{C}$ in the laboratory in 2004 (data not shown) and exhibited little or no dormancy, we expected them to germinate in the field following adequate fall or spring precipitation. Rapid germination did occur in seed bags with adequate precipitation in fall 2003 (26.0 $\mathrm{mm}$ in November). Limited spring 2004 emergence from seeded plots and from the native seedbank on both burned and nonburned plots could be attributed to a number of factors including low over winter survival of germinants, limited precipitation, and the presence or recovery of soil pathogens.

The following year was characterized by a dry fall in 2004 and wet spring in 2005 (Fig. 2). Additional seed bags were not in place during this period. The greater number of seedlings in the field, particularly on the burned site, in spring 2005, 
relative to rosettes developing from root sprouts (Table 3), may demonstrate the advantage of this weather pattern for successful seedling recruitment.

\section{Seed Fate}

Although most rush skeletonweed seeds germinate over a wide temperature range in the laboratory, successful emergence and establishment may occur only occasionally in areas where precipitation is low and erratic. Most seedlings emerged in spring and notably only in the single wet spring. We suspect germination is facultative and that seedlings emerging in winter may not survive. Consequently, occasional favorable years can allow for new seedling recruits, especially if a dry fall and wet spring follow a burn.

Single plants can produce from 15000 to 27000 seeds in a growing season. Given the range of plant densities on our sites $\left(0.18-5.8 \cdot \mathrm{m}^{-2}\right.$ on burned and unburned soils; data not shown), we could expect a range of $2.7-156.6 \times 10^{3}$ seeds $\cdot \mathrm{m}^{-2}$ on our plots. Based on the results of our field and seed bag seedings in 2003 , about $50 \%\left(1.3-78.3 \times 10^{3}\right.$ viable seeds $\left.\cdot \mathrm{m}^{-2}\right)$ were viable when buried, $18 \%$ died in the soil before germinating, and $31 \%$ germinated. About $0.1 \%$ of seeds sown beside the seed bags emerged in 2004 , so $30.9 \%$ died between germination and emergence. The final 1\% (27-1566 seeds $\left.\cdot \mathrm{m}^{-2}\right)$ remained ungerminated but viable after 10 months in the field. Although none of the emergents from the sown plots survived in 2004, emergence from native seeds in the field in 2005 indicates considerable variability may occur from year to year, as in Australia (Panetta 1989).

\section{Potential for Spread of Rush Skeletonweed on the Snake River Plain}

Because of prolific seed production by the species and the ability of the seed to disperse over considerable distances, even a very small percentage of seedling success could result in widespread dispersal of rush skeletonweed. Seeds have undoubtedly contributed to the long-distance dispersal of rush skeletonweed in our region as the species has spread at least $200 \mathrm{~km}$ from the original collection site in southern Idaho (A. Hild and N. Shaw, personal observation, 2007). The potential for increased establishment on burned sites as indicated by this research, coupled with increased wildfire frequency and size on the Snake River Plain will enhance the ability of the species to extend its range here. Additionally, disturbances such as past tilling or openings created by animals such as badgers or other mammals (L. Kinter, personal observation, 2005) seem to create favorable microsites for establishment of rush skeletonweed seedlings, further enhancing the spread of isolated plants. Because of its ability to increase density from root sprouts, we anticipate that isolated seedlings, even in low numbers, can potentially lead to dominance on new sites. This pattern has been noted for other invasive perennial composites of our region (e.g., Russian thistle or hardheads, Acroptilon repens [L.] DC. [Watson 1980]; Canada thistle, Cirsium arvense [L.] Scop. [Moore 1975]; and yellow devil hawkweed, Hieracium floribundum Wimmer \& Grab. [Thomas and Dale 1974]). In our study, fires occurred in late June and early August, allowing considerable time for postfire seed production, which is a common scenario in southern Idaho, but our results would overestimate seedling recruitment in other areas where the fire regime constrains seed production the year of the fire.

\section{MANAGEMENT IMPLICATIONS}

Our results indicate that rush skeletonweed recovers rapidly after fire. Within existing stands, increased plant density will occur primarily via root sprouting following fire or soil disturbance. The prolific seed production of rush skeletonweed appears to be less responsible for increases in plant density than vegetative reproduction within established stands. Extensive burns occurring on annual grasslands create suitable niches for invasion by rush skeletonweed. Managers should monitor the spread of rush skeletonweed by seed when favorable moisture is available following fire or soil disturbance along roadways, croplands, or microdisturbances in native rangeland vegetation. Initial invasion sites provide the most effective time for control of this species and offer an excellent management opportunity. Because small seedling populations can establish dense stands from vegetative growth within a decade, managers should target newly occupied sites.

\section{ACKNOWLEDGMENTS}

We thank Idaho Department of Agriculture State Seed Laboratory Analyst Stacey Bieberdorf, Idaho Department of Fish and Game Boise River Wildlife Management Area Manager Jerry Scholten, Boise State University Biologist Robert Rychert, and USDA Forest Service, Rocky Mountain Research Station employees Stephanie Carlson, Ann DeBolt, Matt Fisk, Jan Gurr, James Hall, Ray Johnson, Rudy King, John Kinney, Alma MadrigalMorfin, Sharon Parkes, Laurie Porth, Danielle Scholten, Melissa Scholten, and Nick Williams. A special thanks goes to USDA Forest Service, Rocky Mountain Research Station statistician David Turner. We also gratefully acknowledge funding provided by the Joint Fire Sciences Program and the USDA Forest Service National Fire Plan.

\section{LITERATURE CITED}

Asher, J., S. Dewey, J. Olivarez, and C. Johnson. 1998. Minimizing weed spread following wildland fires. Proceedings of the Western Society of Weed Science $51: 49$.

Baysinger, O. K., and G. A. Lee. 1980. 1979 survey of exotic noxious weeds in Idaho. Moscow, ID: University of Idaho, Agricultural Experiment Station, Miscellaneous Series 57. 168 p.

Blaney, C. S., and P. M. Kotanen. 2001. Effects of fungal pathogens on seeds of native and exotic plants: a test using congeneric pairs. Journal of Applied Ecology 38:1104-1113.

Blaney, C. S., and P. M. Kotanen. 2002. Persistence in the seed bank: the effects of fungi and invertebrates on seeds of native and exotic plants. Ecoscience 9:509-517.

Boerboom, C. 1993. Rush skeletonweed (Chondrilla juncea L.). Pullman, WA: Washington State University Pacific Northwest Extension, Publication 465. $4 \mathrm{p}$.

CRIST, T. O., And C. F. Friese. 1993. The impact of fungi on soil seeds: implications for plants and granivores in a semiarid shrub-steppe. Ecology 74:2231-2239.

Cullen, J. M., And R. H. Groves. 1977. The population biology of Chondrilla juncea L. in Australia. Proceedings of the Ecological Society of Australia 10:121-134.

CuthBertson, E. G. 1970. Chondrilla juncea in Australia, 3: seed maturity and other factors affecting germination and establishment. Australian Journal of Experimental Agriculture and Animal Husbandry 10:62-66. 
Cuthbertson, E. G. 1972. Chondrilla juncea in Australia, 4: root morphology and regeneration from root fragments. Australian Journal of Experimental Agriculture and Animal Husbandry 12:528-534.

Cuthbertson, E. G. 1974. Seed development in Chondrilla juncea L. Australian Journal of Botany 22:13-18.

Dayan, T., AND D. SimberlofF. 2005. Ecological and community-wide character displacement: the next generation. Ecology Letters 8:875-894.

D’Antonio, C. M., and P. M. Vitousek. 1992. Biological invasions by exotic grasses, the grass/fire cycle, and global change. Annual Review of Ecology and Systematics 23:63-87.

Davis, E. S., P. K. Fay, T. K. Chicoine, and C. A. Lacey. 1993. Persistence of spotted knapweed (Centaurea maculosa) seed in soil. Weed Science 41:57-61.

Dodd, J., and F. D. Panetta. 1987. Seed production by skeleton weed (Chondrilla juncea L.) in Western Australia in relation to summer drought. Australian Journal of Agricultural Research 38:689-705.

ForcelLa, F. 1984. A species-area curve for buried viable seeds. Australian Journal of Agricultural Research 35:645-652.

HaYaSHI, I., AND M. Numata. 1971. Viable buried-seed population in the Miscanthus and Zoysia type grasslands in Japan: ecological studies on the buried-seed population in the soil related to plant succession VI. Japanese Journal of Ecology 20:243-252.

JudD, L., AND K. G. CARn. 1935. Our wheat areas menaced by skeleton weed. The Agricultural Gazette 66:481-486.

LeE, G. A. 1986. Integrated control of rush skeletonweed (Chondrilla juncea) in the western U.S. Weed Science 34(Suppl):2-6.

Liao, J. D., S. B. Monsen, V. J. Anderson, and N. L. Shaw. 2000. Seed biology of rush skeletonweed in sagebrush steppe. Journal of Range Management 53:544-549.

McCaffery, J. P., G. L. Piper, R. L. Callihan, and E. M. Coombs. 1996. Collection and redistribution of biological control agents of rush skeletonweed. Moscow, ID: University of Idaho Cooperative Extension, Bulletin 782. 8 p.

McEvor, P., C. Cox, And E. Coombs. 1991. Successful biological control of ragwort, Senecio jacobaea, by introduced insects in Oregon. Ecological Applications $1: 430-442$.

McVean, D. N. 1966. Ecology of Chondrilla juncea L. in south-eastern Australia. Journal of Ecology 54:345-365.

Middlemist, E. S. 1966. Letter from E. S. Middlemist, Idaho Department of Public Lands Noxious Weed Supervisor, to R Welch, Gem County Weed Supervisor, dated 22 August 1966. Copy on file at Boise, ID: USDA Forest Service, Rocky Mountain Research Station.

Mielke, P. W., JR., And K. J. BerRy. 2001. Permutation methods: a distance function approach. New York, NY: Springer-Verlag. 352 p.

Ministry of Agriculture and Lands. 2004. Rush Skeletonweed (Chondrilla juncea) weed alert, British Columbia. Available at: http://www.agf.gov.bc.ca/cropprot/ rushskel.htm. Accessed 9 January 2007.

Moore, R. J. 1975. The biology of Canadian weeds, 13: Cirsium arvense (L.) Scop. Canadian Journal of Plant Science 55:1033-1048.

[NOAA] National Oceanic and Atmospheric Administration. 2002. Climatography of the United States 81: monthly station normals of temperature, precipitation, and heating and cooling degree days, 1971-2000:10. Idaho. Asheville, NC: National Climatic Data Center. $31 \mathrm{p}$.

[NOAA] National Oceanic and Atmospheric Administration. 2004. Climatological data annual summary Idaho 2004. Asheville, NC: National Climatic Data Center. 24 p.

PanettA, F. D. 1984. Responses of seed populations of skeleton weed to simulated rainfall events. In: R. W. Madin [ED.]. Proceedings of the 7th Australian Weeds Conference. Perth, Western Australia: Weed Science Society of Western Australia. 1:210-214.
Panetta, F. D. 1989. Emergence and early establishment of Chondrilla juncea L. (skeleton weed) in the Western Australian wheatbelt. Australian Journal of Ecology 14:115-122.

Panetta, F. D., And J. Dodd. 1987. The biology of Australian weeds, 16: Chondrilla juncea L. Journal of the Australian Institute of Agricultural Science 53:83-95.

Peters, J. [ed.]. 2000. Tetrazolium testing handbook: contribution 29 to the handbook on seed testing. Lincoln, NE: Association of Official Seed Analysts, Nonpaginated.

Petrondas, D. A., and K. R. Gabriel. 1983. Multiple comparisons by rerandomization tests. Journal of the American Statistical Association 78:949-957.

Prater, M. R., and E. H. Delucia. 2006. Non-native grasses alter evapotranspiration and energy balance in Great Basin sagebrush communities. Agricultural and Forest Meteorology 139:154-163.

Prater, M. R., D. Obrist, J. A. Armone, and E. H. Delucia. 2006. Net carbon exchange and evapotranspiration in post-fire and intact sagebrush communities in the Great Basin. Oecologia 146:595-607.

Pratt, R., And J. Pierce. 2002. Skeleton weed (Chondrilla juncea L.) best practice management guidelines. Bentley, Australia: Agriculture Protection Board of Western Australia, Bulletin 4557. 8 p.

Roche, B. F., JR., ANd C. E. Roche. 1991. Identification, introduction, distribution, ecology, and economics of Centaurea species. In: L. F. James, J. O. Evans, M. H. Ralphs, and R. D. Child [EDS.]. Noxious range weeds. Boulder, CO: Westview Press, Westview Special Studies in Agricultural Science and Policy. p. 274-291.

Rosenthal, R. N., R. Schirman, and W. C. Robocker. 1968. Root development of rush skeletonweed. Weed Science 16:213-217.

Ross, E. P. 1976. Request for funding for an integrated study on rush skeletonweed (Chondrilla juncea) from E. P. Ross, Idaho Department of Agriculture, to the Pacific Regional Commission, dated 19 November 1979. U.S. Department of Agriculture, Forest Service, Copy on file at Boise, ID: Rocky Mountain Research Station.

SAS. [COMPUTER PROGRAm]. 2003. Version 9.1. Carey, NC: SAS Institute, Inc.

Sheley, R. L., J. M. Hudak, and R. T. GrubB. 1999. Rush skeletonweed. In: R. L. Sheley and J. K. Petroff [EDS.]. Biology and management of noxious rangeland weeds. Corvallis, OR: Oregon State University Press. p. 308-322.

Simberloff, D., AND B. Von Holle. 1999. Positive interactions of nonindigenous species: invasional meltdown? Biological Invasions 1:21-32.

Stringer, L. T. 2003. Restoration of spotted knapweed infested grasslands in Glacier National Park [thesis]. Bozeman, MT: Montana State University. 63 p.

Thomas, A. G., And H. M. Dale. 1974. The role of seed production in the dynamics of established populations of Hieracium floribundum and a comparison with that of vegetative reproduction. Canadian Journal of Botany 53:3022-3031.

[USDA, nRCS] US Department of Agriculture, National Resource Conservation Service. 2005. The PLANTS database. Version 3.5. Available at: http:// plants.usda.gov. Accessed 9 January 2007.

[USDI] United States Department of the Interior. 1996. Effects of military training and fire in the Snake River Birds of Prey National Conservation Area. Boise, ID: USDI-US Geological Service-Biological Research Database. 130 p.

Watson, A. K. 1980. The biology of Canadian weeds, 43: Acroptilon (Centaurea) repens L. (DC). Canadian Journal of Plant Science 60:993-1004.

Whisenant, S. G. 1990. Changing fire frequencies on Idaho's Snake River Plain: ecological and management implications. In: D. N. McArthur, E. M. Romney, S. D. Smith, and P. T. Tueller [EDS.]. Proceedings: symposium on cheatgrass invasion, shrub die-off, and other aspects of shrub biology and management. Ogden, UT: U.S. Department of Agriculture, Forest Service. p. 4-10.

ZouHAR, K. 2003. Chondrilla juncea. Available at: http://www.fs.fed.us/database/feis/. Accessed 9 January 2007. 